\title{
Eyewitness Reports of the Great Auroral Storm of 1859
}

\author{
James L. Green \\ NASA/Goddard Space Flight Center \\ Greenbelt, MD 20771 \\ Scott Boardsen \\ L3 Communications Analytics Division \\ NASA Goddard Space Flight Center \\ Greenbelt, MD \\ Sten Odenwald \\ NASA/Goddard Space Flight Center \\ Greenbelt, MD 20771 \\ John Humble \\ School of Mathematics and Physics \\ University of Tasmania \\ Hobart, Tasmania, Australia \\ Katherine A. Pazamickas* \\ Lycoming College \\ Williamsport, PA 17701 \\ *Summer Intern \\ NASA/Goddard Space Flight Center \\ Greenbelt, MD 20771
}

Submitted to Advances in Space Research

August 5, 2005 


\section{ABSTRACT}

The great geomagnetic storm of 1859 is really composed of two closely spaced massive worldwide auroral events. The first event began on August $28^{\text {th }}$ and the second began on September $2^{\text {nd }}$. It is the storm on September $2^{\text {nd }}$ that results from the Carrington-Hodgson white light flare that occurred on the sun September $1^{\text {st }}$. In addition to published scientific measurements; newspapers, ship logs and other records of that era provide an untapped wealth of first hand observations giving time and location along with reports of the auroral forms and colors. At its height, the aurora was described as a blood or deep crimson red that was so bright that one "could read a newspaper by." Several important aspects of this great geomagnetic storm are simply phenomenal. Auroral forms of all types and colors were observed to latitudes of $25^{\circ}$ and lower. A significant portion of the world's 125,000 miles of telegraph lines were also adversely affected. Many of which were unusable for 8 hours or more and had a small but notable economic impact. This paper presents only a select few available first hand accounts of the Great Auroral Event of 1859 in an attempt to give the modern reader a sense of how this spectacular display was received by the public from many places around the globe and present some other important historical aspects of the storm.

\section{INTRODUCTION}

The great geomagnetic storm of 1859 is really composed of two closely spaced massive world-wide auroral displays that nearly covered the globe for hours [Green and Boardsen, 2005]. Reports of the aurora and its effect on telegraphs were believed to "furnish facts of importance to those who look at the phenomena 
from a scientific point of view" [New York Times, September 5, 1859] and were consequently being sent to the editors of the American Journal of Science or the AJS (Silliman, Silliman Jr., Dana and probably others on the editorial board) for publication. The AJS editors first published a collection of these individual contributions before the year was out [Editors, 1859]. In that first publication the editors made a request for additional reports and soon requested E. Loomis, from Yale, to help. In all, nine separate collections of reports were published in the $A J S$ with the editors responsible for the first four and Loomis the remainder, although Loomis has been commonly attributed with them all [Editors, 1859; 1860a; b; c; Loomis, 1860a; b; 1861a; b; 1865].

In the meantime, several other scientists, most notably Joseph Henry, were also collecting and receiving auroral observation reports. "Professor Henry of the Smithsonian Institute was up here [Philadelphia] Monday to make inquiries concerning the phenomenon of Sunday night; and took the statements of all the operators on duty. He appeared much pleased with what he had learned. --Operator American Telegraph Office" [Washington Evening Star News, September 2, 1859]. "We understand that Professor Henry is devoting especial attention to this subject, and it may result in throwing light upon the cause and effect of the Aurora Borealis, so long a subject of discussion among our savans (sic)" [Washington Daily National Intelligencer, Saturday September 3, 1859].

Joseph Henry, the Secretary of the newly formed Smithsonian Institute in Washington DC, had a keen interest in the weather. Knowing that the prevailing wind direction across the US is west to east, he felt certain that weather could be 
predicted on the east coast by looking at the weather the previous day in the mid-west region. As the telegraph became established, Henry had weather reports at $7 \mathrm{AM}$ telegraphed to him at the Smithsonian from a large number of cities. Like reporting the weather, reports of the fantastic 1859 auroral displays were immediately sent to Joseph Henry. It wasn't long before Henry, probably responding to the request from the Editors of AJS, sent his reports to E. Loomis at Yale University. Reports from Henry's collection began to appear in the sixth article in the series [Loomis, 1860b].

In addition to the scientific measurements that were published, newspapers of that era provide an untapped wealth of first hand observations giving us time and location along with reports of the auroral forms and colors. Once recognized, auroral displays were big news for both small local and metropolitan newspapers. If the weather was clear during an auroral display, you could almost guarantee a story in the local news the next day or even a few days later. Newspaper reports of the great aurora rarely got into the scientific journals but they are valuable observations. In this paper, a selection of newspaper and ship $\log$ reports are used to illustrate the truly beautiful nature of this great aurora.

\section{THE AUGUST $28^{\mathrm{TH}}$ EVENT}

The unusually bright and variable auroral forms of the Great Storm, the mostly clear skies, and moonless nights (new moon occurred on August 28 $8^{\text {th }}$ ) all contributed to the very large number of reports of the aurora by the general public in the newspapers. The following are just a few examples of eyewitness accounts. 
“On Sunday evening (in Vermont), the $28^{\text {th }}$ ult, at seven and a half o' clock, we were notified of a large fire behind the mountain at the north, and we went out to see it: and presently the red clouds began to disappear, and spires of green shot up from the same place. It was the most magnificent display ever witnessed in this section; the sky for about an hour more kept changing from green to red, till ten and a half o'clock, when all the brilliancy was gone, except a little green at the north" [Boston Transcript, Monday, September 5, 1859].

"The sky was completely overarched at one time, and then the entire firmament presented a gorgeous spectacle, as the jets of light streaming up from all quarters were of different hues" [Boston Daily Evening Transcript, Monday evening, August 29, 1859].

"At all events, we know of no known cause that would produce such celerity of motion as these merry dancers seemed to have, unless it be galvanism and not electricity" [Boston Transcript, Monday, August 29, 1859].

"At one time the northern portion of the heavens assumed an almost blood red appearance, while here and there long streaks of light shot up from the horizon to the zenith. These rapidly changed their place and their form until they extended over the greater part of the sky, breaking through the reddish hues and finally covering nearly the whole face of the heavens" [New York Herald, August $29,2859]$.

"Objects at a distance could be more readily and clearly distinguished than when the moon is at its full. Now vivid arrows of light of most exceeding brilliancy shot up from the whole northern horizon; and, retreating, would again shoot higher and higher, until they covered the whole sky. This continued to grow darker, first to scarlet, then to crimson, and finally to the blood-red like 
appearance of an immense conflagration. The whole sky appeared mottled-red, the arrows of fire shooting up from the north, like a terrible bombardment, of which we could see all and hear none, while the stars of greater magnitude shone through like sentry lights...Correspondence of the Journal of Commerce, Cleveland, Ohio [Washington Daily National Intelligencer, Friday, September 2, 1859].

"was of extraordinary brilliance. There was a ghastly splendor over the horizon of the North, from which fantastic spires of light shot up, and a rosy glow extended, like a vapor tinged with fire, to the zenith" [Cincinnati Daily Commercial, August 29, 1859].

"The light appeared in streams, sometimes of a pure milky whiteness and sometimes of a light crimson. The white and rose-red waves of light as they swept to and from the corona were beautiful beyond description, and a friend near by us, while looking to the zenith with the whole heavens and earth lighted up at a greater brilliancy than is afforded by the full moon, said that it was like resting beneath the wings of the Almighty. The crown above, indeed, seemed like a throne of silver, purple and crimson, hung and spread out with curtains or wings of dazzling beauty. The tremulous motion of moving light, which the inhabitants of the Shetland Islands call "the merry dancers," was less apparent than usual, but in place of it came those full, bright, changing, but more steady streams of light, which gave an intense brilliancy to the whole heavens" [Washington Daily National Intelligencer, Wednesday, August 31, 1859].

In eastern Australia, where the local time is 15 hours ahead of that in the eastern US, the event was seen on August $29^{\text {th }}$ 
From Tasmania. "It was beyond all conception the most magnificent aurora ever seen in the colony" [The Hobart Town Mercury, Tuesday Morning, August 30, 1859].

"The phenomenon had for 30 minutes a most magnificent appearance, the bands being in complete repose, forming a truncated cone of glory, the apex of which, if projected would have terminated in the zenith. This brilliant and beautiful magneto-electric storm appeared again about 9.30 p.m. flickering in brisk coruscations of most beautiful color from the horizon to the zenith, and when reaching the converging point, it produced at one time a beautiful halo, and at another period it had the effect of falling from the apex in showers of nebulous matter like star-dust" [The Hobart Town Mercury, Wednesday Morning, September 14, 1859].

At Cape Otway, Australia $\left(38.9^{\circ} \mathrm{S}, 143.5^{\circ} \mathrm{E}\right)$ "Aurora Australis most magnificent at 6:30 p.m., and continued visible until after 2 a.m., displaying itself to about 60 to $70 \mathrm{deg}$. First colour above horizon, a light blue with a tint of green blending into second, a very light yellow green, again blending into third, a deep red : the reddy scintillations throughout this coloured light, like opening of a lady's fan; dark heavy clouds" [Melbourne Argus, September 1, 1859].

At Mount Gambier, South Australia $\left(37.8^{\circ} \mathrm{S}, 140.8^{\circ} \mathrm{E}\right){ }^{\prime \prime}$ Last night, at about 7 p.m., a brilliant meteor was seen to shoot through the sky from the S.W. in a N.E. direction, and when near the horizon, burst like a rocket. Almost immediately afterwards the rays of an aurora Australis were most brilliantly visible in the N.E" [Melbourne Argus, September 1, 1859].

At Alelaide. "A very brilliant meteor was seen towards the south, which fell in a curve from about $45 \mathrm{deg}$. elevation, standing to the eastward. Almost 
immediately following this the glancing rays of a vivid aurora shot up the sky, at first more fully developed to the west, but afterwards stretching across the whole of the south from the hills to the sea. The line worked very badly through the whole day" [Melbourne Argus, September 1, 1859].

In Sydney, Australia "Yesterday morning at about 10 o'clock, the wires of the electric telegraph were seized with an unaccountable fit of restiveness; they did not altogether refuse to work, but acted irregularly, the adjustment of the instruments altering so frequently that it was almost impossible to get any continuous message through. Everywhere the instruments were jammed. The wires continued to display their obstinacy till the evening, when the cause of the mystery was, to some extent, cleared up. A bright red light in the south-west quarter of the heavens, made many at first suspect that a great fire had broken out somewhere, but the changing hues and forms of light revealed at last to the initiated the Aurora Australis" [The Sydney Morning Herald, August 30, 1859, page 4].

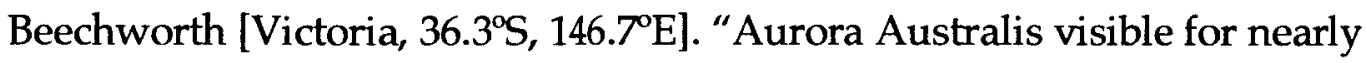
an hour and a half, commencing about 5.45 p.m., gradually increasing in beauty and brilliancy of tint until shortly before 7 , when the rays became gradually indistinct, disappearing at about 7.15 p.m. No thunder or lightning observed, but during the whole day the wires strongly affected" [Melbourne Argus, September $1,1859]$.

"The southern sky was then of a light reddish tint, which gradually grew deeper till at $7 \mathrm{~h} .20 \mathrm{~m}$., it arrived at a maximum. The spectacle presented by the southern heavens at this time was very impressive, the sky being of a deep blood-red colour " [The Sydney Morning Herald, September 1, 1859]. 
From Moreton Bay [now called Brisbane, $27.5^{\circ} \mathrm{S}, 153^{\circ} \mathrm{E}$ ], and the farthest northern sighting documented from Australia. "Most of our readers saw last week, for three nights, commencing after sunset and lighting up the heavens with a gorgeous hue of red, the Southern Aurora." The difference in the appearance of the Auroras in Queensland to that spoken of by Mr. Scott [in Sydney] is, we had three nights of beauty, brought to a finale early on Saturday morning, after the greater space of red light and rays and visible starts, through the Aurora, lasting with slight variations for eight hours" [The Moreton Bay Courier, Wednesday, September 7, 1859].

Ship deck logs, archived at the National Archive and Records Administration (NARA) were keep on both merchant and military ships, filled out by the sailor on watch, and typically contained information on weather conditions, sighting of other ships, crew activities, and even observations of aurora. Many of the US military ships in overcast Japan missed the auroral displays, however, several in the Atlantic and the Pacific, at very low latitudes, noted the aurora. Nearly all the reports were of the red aurora. The reports included:

"We witnessed the most magnificent display of the aurora boreales (sic) imaginable. It began from NE to NW and would shoot up to the Zenith at 1[AM on September 2] the whole firmament was a blaze of Crimson shooting up from all points of the compass but the most splendid from the South $W$. I have not the language to describe it" [Messenger, Latitude $49^{\circ} 09^{\prime}$; Longitude $67^{\circ} 28^{\prime}$ NARA, Record Group 27].

“At $8 \mathrm{PM}, 28^{\text {th }}$, a beautiful Crimson aurora or Zodiacal light is visible, it is whitest to the North but a beautiful Crimson in the west as if borrowing the 
sunset to colourish (sic) shafts of light which flecked the sky from the horizon up to about $50^{\circ}$, of alt [altitude]. By $9 \mathrm{PM} 3 / 5$ th of the sky was covered and the apex of the deep blood red cone of light that tip pass (sic) the constellation Lyra. It continued all night and to the last [morning of the $29^{\text {th }}$ ] retained its crimson appearance" [Arcole, Latitude 41 $40^{\prime}$; Longitude $46^{\circ} 45^{\prime}$ NARA, Record Group 27].

"The whole heavens became brilliantly illuminated" [Latitude $37^{\circ} 24^{\prime} \mathrm{N}$; Longitude $65^{\circ} 51^{\prime} \mathrm{W}$, Savannah, NARA, Record Group 24].

The "heaven became illuminated with a crimson glow passing from the $\mathrm{N}$. and $\mathrm{W}$. to the S. supposed to be the northern lights" [Release, Latitude $35^{\circ} 31^{\prime} \mathrm{N}$; Longitude: $60^{\circ} 14^{\prime} \mathrm{W}$, NARA, Record Group 24].

"during the watch to the $\mathrm{N} \& \mathrm{E}$ was seen an aurora borealis, brilliantly red" [Saranac, Panama, NARA, Record Group 24].

"The aurora was a "deep rosy red" [Sabine, Latitude $11^{\circ} 32^{\prime} \mathrm{N}$; Longitude $83^{\circ} 49^{\prime}$ W NARA, Record Group 24].

As an example of what these observers might be trying to describe, Figure 1 shows a photograph of a type A red aurora observed in Hokkaido, Japan on October 21,1989 . In this example, the deep rosy red aurora was very diffuse, with little or no structure and was observed to blanket most of the sky similar to that observed by many eyewitnesses of the great aurora of August 28-29 and September 2-3, 1859. More recently, Nakazawa et al. [2004] have cataloged 16 giant low latitude red auroras as seen from Japan in the span of about 800 years dating from $1150 \mathrm{AD}$ to the 1859 event. Other catalogs of these types of events exist [c.f. 
Jones, 1992]. Based on the similarity of all these events is clear is that although the great auroral event of 1859 may be the largest one recorded it is by no means a rare event on the time scale of $100-200$ years.

\section{SEPTEMBER $2^{\mathrm{ND}}$ EVENT}

Four days later, another massive world-wide auroral event occurred. The following articles are also eyewitness accounts, and are even more vivid than what occurred on August 28.

"The exhibition of the Aurora on Thursday night and Friday morning, exceeded in brilliancy that of last Sunday evening; but upon the last occasion it was chiefly confined to the southern heavens [south of New York City], and hence was more properly an Aurora Australis than an Aurora Borealis" [New York Times, September 3, 1859].

"During the first display the whole of the northern hemisphere was as light as though the sun had set an hour before, and luminous waves rolled up in quick succession as far as the zenith, some a brilliancy sufficient to cast a perceptible shadow on the ground" [The Times London, September 6, 1859].

"Some who saw the display attributed it to fires in the towns about" [Rochester Union \& Advertizer NY, Friday, September 2, 1859].

"About $10[\mathrm{PM}]$ a tremulous flashing up from the east was observed - soon after a bank-like arc of a circle was seen in the North, below which, the appearance was very somber, resembling a very dark cloud. From this arc soon shot up columns of light toward the zenith. This was immediately succeeded by the most lively and brilliant succession of flashes, forcibly reminding one of that prophetic scene described by St. Peter, whose language is - "Wherein the 
heavens being on fire shall be dissolved, and the elements shall melt with fervent heat." This grand and sublime exhibition was succeeded by another brilliant display of columns of light shooting up again from the arc, with a slight show of the merry dancers. Soon after this the light gradually faded and ceased to attract much notice" [Boston Transcript, Saturday September 2, 1859].

"When first seen, the aurora omitted a thin pale light, which flashed up toward the center of the overhanging arch. Simultaneous with these flashes, long illuminated lines extended to the same point, which became redder and redder, till one assumed nearly a crimson color" [Boston Transcript, September 3, 1859].

"The auroral light sometimes is composed of threads like the silken warp of a web; these sometimes become broken, and fall to the earth" [Providence Daily Post, Rode Island, September 3, 1859].

"There was another display of the Aurora last night so brilliant that at about one o' clock ordinary print could be read by light" [The New York Times, New York Herald, Washington Daily National Intelligencer, September 2, 3, 5, 1859].

"It was reserved for our days to have a sage and philosopher to make clear to our comprehension the wonderful mysteries of those lights, which the Scotch know as merry dancers but with which we are more familiar by their Latin name of aurora borealis, to show us that they are nothing more nor less than an industrial exhibition of the upper air, a silkery (sic) in the clouds, whereat the magic shuttle flies from horizon to zenith with a speed that leaves electricity lagging far behind, and to be prepared to exhibit to the incredulous world a piece of the product of these heavenly looms... Phenomena are not supposed to have any reference to things past --- only to things to come. Therefore, the aurora borealis cannot apply to the battle of Solferino or the peace of Villaranca. It must 
be connected with something in the future --- war, or pestilence, or famine. They may be connected in some way with volcanic eruptions, or earthquakes, or, as has been long supposed, with icebergs. As philosophers are unable to solve the problem, why do not the aeronaunts try it? Wise and La Mountain have been threatening transatlantic voyages. Suppose that, before they start for the other side, they would ascend in their balloons and try to get a glimpse of the foundation line of the aurora borealis" [New York Herald, September 5, 1859].

"Aurora appeared, illuminating the city so brightly as to draw crowds into the streets" [New York Times, September 5, 1859].

"But two hours later, when the light, as a whole, was at its greatest brilliancy, the northern heavens were perfectly illuminated, with the exception of a few dim and almost imperceptible white streamers, which passed from the zenith nearly half way down to the northstar (sic). At that time almost the whole southern heavens were in a livid red flame, brightest still in the southeast and southwest. Streamers of yellow and orange shot up and met and crossed each other, like the bayonets upon a stack of guns, in the open space between the constellations Aries, Taurus and the Head of Medusa - about 15 degrees south of the zenith. In this manner - alternating great pillars, rolling cumuli shooting streamers, curdled and wisped and fleecy waves - rapidly changing its hue from red to orange, orange to yellow, and yellow to white, and back in the same order to brilliant red, the magnificent auroral glory continued its grand and inexplicable movements until the light of morning overpowered to radiance and it was lost in the beams of the rising sun" [New York Times, September 3, 1859].

"Early in the evening from the east there came a faint light, like that preceding the rising moon, while in the west a delicate crimson seemed to be 
thrown upwards, as if from the sun, long since gone down. Later, these strange fires overran the entire heavens - now separating into streamers, gathered at the zenith, and forming a glorious canopy - then spreading evenly like a vapor, shedding on all things a soft radiance; again, across the sky waves of light would flit, like the almost undistinguishable ripple produced by the faintest breeze upon the quiet surface of an inland lake; a pale green would now cover half the firmament from the east, while rich crimson met it from the west - then the ruddy light would concentrate itself at the zenith, while beneath it fell in folds of beauty the mild purple and green. To the east and to the west lay huge fields of luminous clouds, tinted with a bright rosy flush, wholly unlike that produced by the rising sun and if possible even more beautiful. Soon, as Everett has beautifully spoken of a somewhat similar scene, "the hands of angels shifted the glorious scenery of the heavens." The mass of apparent, red cloud to the east moved away southward, gradually failing, while the corresponding red clouds on the west seemed to sink into a chaos of dark cloud that, with a fringe of blue, skirted the western horizon. - Sheets of the same white luminous cloud again illuminated the sky, producing about the same amount of light as the full moon, and the night became almost as the day. The aurora borealis is today the chief topic of conversation, and all agree that they have seldom or never witnessed so extensive and remarkable an atmospheric phenomenon" [Cincinnati Daily Commercial, September 1, 1859].

"Half-past eleven. The appearance now is positively awful. The red glare is over houses, streets, and fields, and the most dreadful of conflagrations could not cast a deeper hue abroad" [San Francisco Herald, September 5, 1859]. 
"The whole sky appeared to undulate something like a field of grain in a high wind; the waters of the Bay reflected the brilliant hues of the Aurora. Nothing could exceed the grandeur and beauty of the sight; the effect was almost bewildering, and was witnessed with mingled feelings of awe and delight by thousands. Nebulous matter, like that which furnishes material for meteoric showers, or the zodiacal light, and is known to exist in the planetary spaces, is probably the cause of these displays. He regards the light as emitted by the friction of the earth, plunging with its atmosphere, through this vapor, the velocity being sufficient, despite the rarity of the materials, to develop the luminosity" [San Francisco Herald, September 5, 1859].

"Large print could no doubt have been easily read, for we can testify that the time on the face of a watch was easily legible" [Washington Daily National Intelligencer; September 3, 1859].

“On Thursday night last about eleven o'clock our attention was attracted by the red appearance of the sky in the N. East, which we at first supposed was the reflection from a fire in that direction, but it began to spread on both sides and was pronounced by those who knew, to be the Aurora Borealis or Northern Light. About half past eleven it began to assume the appearance of day breaking and in ar: hour it was almost as light as day, the stars, which before shown brightly being invisible; at one o'clock the light began to fade and in an hour the heavens had assumed their usual appearance and the stars shown out bright as ever, and, turned in" [Rocky Mountain Gold Reporter, September 3, 1859].

“On the night of [September 1] we were high up on the Rocky Mountains sleeping in the open air. A little after midnight we were awakened by the auroral light, so bright that one could easily read common print. Some of the party 
insisted that it was daylight and began the preparation of breakfast. The light continued until morning, varying in intensity in different parts of the heavens, and slowly changing position. We can best describe it as the sky being overcast with very light cirrus clouds, wafted before a gentle breeze, and lighted up by an immense conflagration. It had rained for fifty hours before, only ceasing about twelve hours before the auroral light" [Rocky Mountain News, September 17, 1859].

"It is an indisputable fact that old topers, wholesale consumers of the alcoholic fluid, whose capacious stomachs could retain an enormous quantity of the "creature" without their heads or legs being in the least affected by it, have fallen dead drunk last night and last Sunday night, before they had imbibed their regular allowance, and through no other cause than the mysterious influence upon their system of the unexplained electrical phenomenon, shining overhead" [New Orleans Daily Picayune, September 3, 1859].

"The northern sky, for an extent of some forty-five degrees, was luminous with a mass of red light, from whence shot up towards the zenith the usual streaks, at times vivid and beautiful" [New Orleans Daily Picayune, September 3, 1859].

"again appeared in most resplendent brilliancy in the northern horizon last evening, being visible for a while just before and after the hour of midnight. The fainter or yellow lines of upshooting light could be clearly distinguished in the bright red illumination which extended wide around, lighting up the sky in such a manner as led the unmindful and even some of the fire companies to suppose that part of the city was about to be burnt out in a grand conflagration" [The New Orleans Bee, September 2, 1859]. 
"Singular as it may appear, a gentleman actually killed three birds with a gun yesterday morning about 1 o'clock, a circumstance which perhaps never had its like before. The birds were killed while the beautiful aurora borealis was at its height, and being a very early species - larks -- were, no doubt, deceived by the bright appearance of everything, and came forth innocently, supposing it was day" [New Orleans Daily Picayune, September 9, 1859].

"All our exchanges, from the northern coast of the Island of Cuba (from the southern side we have none so late,) come to us with glowing descriptions of the recent Aurora Borealis, which appears to have been as bright in the tropics as in the northern zones, and far more interesting. The sky was no more, or at least but for a moment, completely lit up from the horizon to the pole, but the light came and went, now here, now there, now in this direction, now in that, and each time varying in outline and brilliancy. During the three hours which followed it seems to have had almost every latitude and longitude possible in its field, and to have described every possible figure" [New Orleans Daily Picayune, September 7, 1859].

From Melbourne, Australia. "About a quarter before 12, the higher heavens were the scene of magnificent converging cones of light, the declination instrument showing a most remarkable amount of disturbance. The red glare illuminated the earth and tinged even the whole of the northern horizon. Subsequently to this the heavens gradually became suffused with clouds, and the phenomenon disappeared from observation" [Melbourne Argus, September 3, 1859].

\section{TELEGRAPH OPERATIONS AND ECONOMIC IMPACT}


Today it is well known that a geomagnetic storm can have a massive impact on our economy. Our economy and the functioning of our society is, by in large measure, critically dependent on the availability of electricity. Great geomagnetic storms can knock out power grids and wreak havoc on the operations of our space assets affecting, for example, a whole host of communication services we now take for granted. It might be hard for us to imagine today but even for such a relatively low-tech society of the 1850's the great geomagnetic storm of 1859 did have an economic and social impact. The great geomagnetic storm affected a significant part of the worldwide telegraph communication system.

In $1859,100,000$ to 125,000 miles of telegraph lines existed in the whole world [New York Herald, September 4, 1859]. The telegraph was used extensively to transmit information of all kinds around the US (although the east coast and west were not directly connected at that time), Australia, India and within Europe. In August 1858 the first transatlantic link became operational for only twenty days before it failed and a new cable was to be installed by the end of 1860. Newspapers used the telegraph system to provide the public with timely news stories as Associated Press releases of today. Newspaper banners such as "By Telegraph" and "The Latest News by Telegraph" were standard feature articles in large city newspapers.

It was widely reported that, beginning in the evening of August $28^{\text {th }}$, the telegraph lines were disrupted, and telegraph operators were left with lines that were completely useless. Here are just a few first hand accounts. 
"The French telegraph communications at Paris were greatly affected, and on interrupting the circuit of the conducting wire strong sparks were observed. The same thing occurred at the same time at all the telegraphic station in France" [The Illustrated London News, September 24, 1859].

"Never in my experience of fifteen years in working telegraph lines have I witnessed anything like the extraordinary effect of the Aurora Borealis between Quebec and Farther Point last night. The line was in most perfect order, and well skilled operators worked incessantly from 8 o'clock last evening till 1 this morning to get over in an intelligible form four hundred words of the report per steamer Indian for the Associated Press, and at the latter hour so completely were the wires under the influence of the Aurora Borealis that it was found utterly impossible to communicate between the telegraph stations, and the line had to be closed. The same difficulty prevailed as far south as Washington" [Rochester Union \& Advertizer, Tuesday Evening August 30, 1859].

"The New York operator, J.C. Crosson, reported as follows: On Sunday evening last, at 7-1/2 o'clock, I experienced considerable difficulty in working on account of the variation of current. Upon looking out the doors I perceived broad rays if light extending from the zenith toward the horizon in almost every direction. I then concluded the difficulty arose from the mysterious influence of the Aurora Borealis" [Cincinnati Daily Commercial, September 7, 1859].

"The telegraph operators throughout the east report a very brilliant display of auroral light, which though very fine to look at, has as usual greatly hindered the transmission of messages over the wires" [Philadelphia North American \& United States Gazette, Monday Morning, Aug. 29, 1859]. 
"Lousiville KY, August 31-The telegraph wires between this city and New York, as also throughout Canada, were interrupted by the unusual overcharge of electricity which always pervades the atmosphere during the continuance of this phenomenon" [The New Orleans Bee, September 1, 1859].

The second massive auroral storm on September 2, 1859 also caused disturbances in the telegraph system. However, these eyewitness accounts report the auroral current taking the place of the galvanic battery.

"The wire was then worked for about two hours without the usual batteries on the auroral current, working better than with the batteries connected. This is the first instance on record of more than a word or two having been transmitted with the auroral current" [Washington Daily National Intelligencer, Tuesday, September 6, 1859].

. "Who now will dispute the theory that the Aurora Borealis is caused by electricity" [Washington Evening Star News, September 2, 1859]:

"During the auroral display on Thursday night in Boston some curious phenomena were witnessed in connection with the telegraph wires. The following conversation, says the Boston Traveler, between the Boston and Portland operators on the American telegraph line, will give an idea of the effect of the Aurora Borealis, on the working of the telegraph wires:

Boston operator, (to Portland operator)--“Please cut off your battery entirely from the line for fifteen minutes."

Portland operator-“Will do so. It is now disconnected."

Boston-"Mine is disconnected, and we are working with the auroral current. How do you receive my writing?" 
Portland-Better than with our batteries on. -Current comes and goes gradually."

Boston-"My current is very strong at times, and we can work better without the batteries, as the Aurora seems to neutralize and augment our batteries alternately, making current too strong at times for our relay magnets. Suppose we work without batteries while we are affected by this trouble."

Portland-“Very well. Shall I go ahead with business?"

Boston-“Yes. Go ahead."

The wire was then worked for about two hours without the usual batteries, on the auroral current, working better than with the batteries connected. The current varied, increasing and decreasing alternately, but by graduating the adjustment to the current, a sufficiently steady effect was obtained to work the line very well. This is the first instance on record of more than a word or two having been transmitted with the auroral current. The usual effects of the electric storm were manifested, such as reversing the poles of the batteries, etc" [The Daily Chronicle and Sentinel, Augusta, Georgia, Thursday AM, September 8, 1859].

"There were strong currents of electricity observed on the wires, to which no batteries were attached, and some extraordinary electrical phenomena, difficulty of explanation, noticed" [New Orleans Daily Picayune, Saturday, September 3, 1859].

"Friday morning last, the morning of the last auroral borealis, the operators of the National Telegraph office in Washington City found, on going to their business, a series of electrical currents, entirely independent of the batteries, in possession of the wires. These currents seem to have been manageable, for the operators actually went to work and send messages from New York to Pittsburg, PA., correctly without the use of a particle of galvanic battery, using this 
independent electricity of the air in the place of that supplied by the ordinary batteries" [New Orleans Daily Picayune, September 9, 1859].

In addition to the technological issues posed by these 'earth currents' entering the telegraph lines, was the very real potential for direct human injury. The most spectacular, and now legendary, story is told by Frederick Royce: a telegraph operator working in Washington DC, at his station between 8 and 10 PM.

"I did not know that the Aurora had made its appearance until 8 or $81 / 2$ o'clock. I had been working 'combination' to Richmond, and had great difficulty from the changing of the current. It seemed as if there was a storm at 'Richmond'. Concluding that this was the case, I abandoned that wire and tried to work the Northern wire, but met with the same difficulty. For five or ten minutes I would have no trouble, then the current would change and become so weak that it could hardly be felt. It would then gradually change to a 'ground' so strong that I could not lift the magnet. While the Aurora lasted the same phenomena were observable. There was no rattling or cracking of the magnet, as is the case in a thunder storm. I looked at the paper between the arrestors, but found no holes. Philadelphia divided the circuit at the request of New York, and we succeeded in getting off what business we had. The Aurora disappeared a little after 10 o'clock - after which we had no difficulty, and we worked through to New York. During the display I was calling Richmond, and had one hand on the iron plate. Happening to lean towards the sounder, which is against the wall, my forehead grazed a ground-wire which runs down the wall near the sounder. Immediately, I received a very severe electric shock, which stunned me for an instant. An old man who was sitting facing me, and but a few feet distant, said 
that he saw a spark of fire jump from my forehead to the sounder. The Morse line experienced the same difficulty in working" [New York Times, September 5, $1859]$.

The August-September 1859 superstorm was unique, not only in terms of its severity and geographic distribution across the entire developing world, but because of its widespread impact on telegraphic systems of that time. There was also far greater commercial and news reportage use of telegraphy by 1859 since it had become a 'mature' and low-risk telecommunications resource. A simple assessment of the economic impact of this storm can be made by considering the fraction of the 1500 domestic telegraph stations that were affected, the number of hours out of service, and the estimated normal profitability of a 'typical' operator.

The typical telegraph operator produced $\$ 75 /$ day to the company [Scientific American, November 26, 1859] and the cumulative number of hours of out-ofservice operation for both storm events was August 28-29 (12 hours) and September 2-3 (12 hours). Not all domestic telegraph lines were out of service, based on the records from New England and the Eastern States, so one might estimate that not more than half the stations were affected. The product of these factors leads to $\$ 56,000$ in seemingly 'lost' revenue. European stations were also affected, however their numbers and economic revenue are not known. The number of lines available in the aggregate sun were 120,000 miles world-wide, of which the US share was about 25,000 miles, so that a reasonable estimate might be $\$ 56 \mathrm{k} \times 120,000 / 25,000=\$ 270,000$ globally. This assumes about the same 
number of telegraph stations per mile of line as in the US (1 station every 17 miles) and the same revenue and outage factor. Of course, this only assesses the proximate losses by the telegraph operator for the service.

The problem with this calculation is that, the probable effect of the aurora on message transmission was that the message would be re-transmitted later and not canceled, so one could assume that with the exception of time-critical messages, there was no actual economic loss to the recipient. However, there would still be an impact to the telegraph company for an unprofitable loss of time by its work force to auroral interference. The annual salary for a typical operator was about $\$ 1000$ / year or about $\$ 3$ per day. The number of operators that were idled by this storm, or forced to re-transmit the same message multiple times, is equal to the number of stations affected, or about 750. Even assuming a full day's loss of work, this only amounts to $\$ 2,200$ for domestic operators, and perhaps 5 times this for the global community.

Combining the revenue loss with the operator labor loss, the total global impact would not have been more than perhaps $\$ 300,000$. This doesn't sound like a major loss for an event that produced no other physical damage to the infrastructure requiring later repairs. What we cannot include, however, is the collateral impact to users of this global network. These impacts could have included stock market transactions not made on time, emergency family messages, and a variety of confirmation messages for meetings and travel arrangements, to name a few possibilities. Other than the occasional anecdote 
reported in the newspapers, we have no contemporary means to truly gauge the economic impact of these two auroral events.

The cited telegraph problems caused by the August 28 - September 2 storms settled a long-standing controversy among telegraph engineers and auroral scientists of ca 1859, and demonstrated that the aurora was associated with naturally occurring currents. If a worldwide event like the great auroral storm of 1859 were to happen today the economic result may very well be devastating [see for example: Odenwald et al., 2005; Kappenman et al., 1997].

\section{EVENTS ATTRIBUTED TO THE GREAT AURORA}

It is very difficult, today, to imagine how truly unique these displays were to the general public. Many of the accounts mention that no one could recall a more spectacular aurora. The following reports give some account of the thoughts of the general public as a result of the great auroral storm in 1859 .

"The present generation have listened with wonder and admiration to the stories their fathers and mothers have told them of auroras and meteors. They have opened their ears and mouths and eyes as they heard of stars falling from the heavens like rain, of the sky at night becoming read as with blood, and in the day time of its being so darkened that stars were visible. Few have had the opportunities of witnessing these sublime displays; but on Sunday night the heavens were arrayed in a drapery more gorgeous than they have been for years... Such was the aurora, as thousands witnessed it from housetops and from pavements. Many imagined they heard rushing sounds as if Aeolus had let loose winds" [New York Times, August 30, 1859] 
"Crowds of people gathered at the street corners, admiring and commenting upon the singular spectade. Many took it to be a sign of some great disaster or important event, citing numerous instances when such warnings have been given" [New Orleans Daily Picayune, Monday, August 29, 1859].

Because of their uniqueness, some individuals found themselves deeply affected either emotionally or intellectually. The famous American poet William Ross Wallace (1819 - 1881) was a well-known and admired contributor to newspapers and magazines of the time, and penned a poem about the aurora, which was published in The East Floridian, September 15, 1859. Here is a short excerpt from it:

\section{...O ye wonderful shapes}

With your streamers of light

Blazing out o'er the earth

From your ramparts of night;

With your strange hazy hues;

With your swift-changing forms,

Light the red-lightning rush

Of fierce tropic storms -

O ye terrible shapes!

Yet through all still appear

Yonder love-speaking eyes

Of the far starry sphere;

So 'mid terror, we still

Can a symbol behold

Of the Heavenly Love

In the flame o'er us rolled;

Evermore, evermore

Though in mantles of fire, 


\section{There are pitying smiles}

From our God and our Sire -

O Lights of the North! As in eons ago,

Not in vain from your home do ye over us glow!

There is also some suggestion that the famous American painter Frederick Edwin Church (1826 - 1900) may have used these aurora as the inspiration for his painting 'Aurora Borealis'. Biographers note that he was in Labrador and Newfoundland during the late summer of 1859 doing research for his painting 'Icebergs'. It is impossible to imagine that he, as with so many other millions of people, did not also admire the August-September aurora, and perhaps use it as the basis for his 1865 painting.

While some individuals found themselves inspired by the aurora, there is evidence that others found themselves greatly disturbed by the event, at a time in history when fears of the end of the Earth were making their rounds in many religious circles. By September 4, in the minds of some people, the spate of spectacular aurora spanning an intense one-week interval took on much more than a simple diversion from normal daily affairs. A Columbus, Ohio sixteen year old girl "of considerable intelligence and prepossessing appearance", who had been taken into custody by the Sheriff of Ottawa County was particularly effected by the aurora.

"Her agitated state necessitated that she be moved to the lunatic asylum. The conclusion drawn from this, and no doubt her utterances, implied that she had become deranged from viewing the aurora borealis a short time ago. She 
was convinced that all of this spectacular auroral activity meant that the world was soon to come to an end" [Harpers Weekly, October 8, 1859]

While artists and poets mused about the cosmos and what such a spectacle might mean in human terms, other people living in a more mundane world scrambled to preserve their sanity, and still others found time to comment on the more humorous aspects of the event.

"To the editor of the Evening Post: I received the specimens of Aurora Borealis which you sent by Moonray's Express, and found them to correspond precisely with others which were collected in this vicinity. Having subjected them to chemical analysis, I append the result which you will not hesitate to publish for the advancement of science. [The] last analysis - Hairs of dog tail. This is conclusive. Mr. Moonray's dog died a year since, and ascended to the third sphere, beyond the great cycle. Coming in contact with Canis Major a terrible conflict ensued, which made the fur fly. In its fall it was converted into silk, and coming in contact with the rainbows and sulphur of lightning, hence its various colors" [Cincinnati Daily Commercial, September 5, 1859].

"The influence of the Aurora Borealis has been felt in the Garden District. We see in the police reports, this morning, that several denizens of that delightful spot have been found drunk - many under a strange delusion, having taken the gutter for their own comfortable beds" [The New Orleans Daily Picayune, Wednesday, September 7, 1859].

6. EXPLANATIONS OF THE AURORA AND SCIENTIFIC PROGRESS 
The massive world-wide auroal displays begged for better explanation of the aurora. Popular explanations of the ray structure of the aurora included:

- Falling matter from erupting volcanoes [Scientific American, November 12, 1859]

- "Nebulous matter... known to exist in planetary spaces" similar to meteors falling into the atmosphere [San Francisco Herald, September 5, 1859]

- Reflected light from icebergs or polar ice [New York Herald, September 5, 1859; Harper's Weekly, October 1, 1859]

Scientifically, before this event, many like Loomis believed that the aurora was a higher altitude version of lightning (entirely of Earth origin) but the great auroral event of 1859 marked a new change in thinking. Loomis [1865] used several nearly simultaneous observations of the aurora to establish its height. For the September 2-3, 1859 aurora he concluded that "the aurora... formed a belt of light encircling the northern hemisphere, extending southward in North America to latitude $221 / 2^{\circ}$, and reaching to an unknown distance on the north, and it pervaded the entire interval between the elevation of 50 and 500 miles above the earth's surface." In his report to the Smithsonian [Loomis, 1865] Loomis stated, "we are thus led to regard great auroral displays as no longer an exclusively atmospheric phenomenon, and as being, to an important extent the result of the influence of extra-terrestrial forces." Even Carrington stated that the connection between the observation of the solar white light flare on September $1^{\text {st }}$ preceding the geomagnetic storm of September 2-3 "may deserve noting", but he would not move "towards hastily connecting them" [Carrington, 1860]. More solar- 
terrestrial connection data was needed before the undeniable connection would be established.

The great auroral display not only provided important new observations for the scientific community but helped change public perceptions. As was noted in many newspapers "a connection between the northern lights and forces of electricity and magnetism is now fully established" [Scientific American, October $15,1859]$. "Henceforth no one can be excused if he talks about the reflection from the polar seas of ice. We have practical evidence that the aurora is, or contains, the electrical fluid [current]" [Harper's Weekly, October 1, 1859].

\section{ACKNOWLEDGEMENTS}

The authors are grateful to an anonymous referee for a clearly pointing out the sequence of events surrounding the authorship of the $A J S$ articles on this storm. In addition, the authors are grateful to Dr. Peggy Shea for her constant encouragement. Marc Rothenberg at the Smithsonian Institution Archives is acknowledged for his unique insight into Joseph Henry and access to important archival information. The authors would like to thank Nancy Gessner and Justin Robinson who worked diligently helping to transcribing first hand accounts of the great auroras.

\section{REFERENCES}

Boston Daily Evening Transcript, Issue dated August 29, 1859.

Boston Transcript, Issues dated August 29, August 30, September 2, September 3, September 5, 1859. 
Carrington, R. C., Description of a singular appearance seen in the sun on September 1, 1859, Mon. Not. R. Astron. Soc., XX, 13, 1860.

Cincinnati Daily Commercial, Issues dated August 29, September 1, September 5, September 7, 1859.

Editors, The great auroral exhibition of August $28^{\text {th }}$ to September 4, 1859, Am. J. Sci., Vol. 28, No. 84, 385-408, 1859.

Editors, The great auroral exhibition of August $28^{\text {th }}$ to September 4, $1859-2 d$ article, Am. J. Sci., Second Series, Vol. 29, No. 85, 92-97, 1860a.

Editors, The great auroral exhibition of August $28^{\text {th }}$ to September 4, $1859-3 \mathrm{~d}$ article, Am. J. Sci., Second Series, Vol. 29, No. 86, 249-265, 1860b.

Editors, The great auroral exhibition of August $28^{\text {th }}$ to September 4, $1859-4$ th article, Am. J. Sci., Second Series, Vol. 29, No. 87, 386-397, 1860c.

Green, J. L. and S. A. Boardsen, Duration and extent of the great auroral storm of 1859, Adv. in Space Res., This Issue, 2005.

Harper's. Weekly, Issues dated September 10, October 1, 1859.

Harper's Weekly, Issue dated October 8, 1859

Hodgson, R, On a curious appearance seen in the sun, Mon. Not. R. Astron. Soc., $X X, 15,1860$.

Jones, A. V., Historical review of great auroras, Can. J. Phys., 70, 479-487, 1992.

Kappenman, J. G., L. J. Zanetti, and W. A. Radasky, Geomagnetic storms can threaten electric power grid, Earth in Space, 9, 9-11, March 1997.

Loomis, E., The great auroral exhibition of August $28^{\text {th }}$ to September $4,1859-$ 5th article, Am. J. Sci., Second Series, Vol. 30, No. 88, 79-94, 1860a.

Loomis, E., The great auroral exhibition of August $28^{\text {th }}$ to September 4, 1859-6th article, Am. J. Sci., Second Series, Vol. 30, No. 90, 339-361, 1860b. 
Loomis, E., The great auroral exhibition of August $28^{\text {th }}$ to September 4, $1859-7$ th article, Am. J. Sci.,Second Series, Vol. 32, No. 94, 71-84, 1861a.

Loomis, E., On the great auroral exhibition of Aug. $28^{\text {th }}$ to Sept. 4, 1859, and on auroras generally, Am. J. Sci., Vol. 32, No.96, 318-331, 1861 b.

Loomis, E., The aurora borealis, or polar light; its phenomena and laws, Annual Report of the Smithsonian Institution, 208-248, 1865.

Melbourne Argus, Issues dated September 1, September 3, 1859.

Nakazawa, Y., T. Okada, and K. Shiokawa, Understanding the "SEKKI" phenomena in Japanese historical literatures based on the modern science of low-latitude aurora, Submitted to EPS, 2004.

National Archive and Records Administration, Record Group 24.

National Archive and Records Administration, Record Group 27.

New Orleans Bee, Issues dated September 1, September 7, 1859.

New Orleans Daily Picayune, Issues dated August 29, September 3, September 7, September 9, 1859.

New York Herald, Issues dated August 29, September 3, September 4, September $5,1859$.

New York Times, Issues dated August 30, September 2, September 3, September $5,1859$.

Odenwald, S.F., 'The 23rd Cycle:Learning to live with a stormy star', Columbia University Press: NY, 2000.

Odenwald, S. F., J. Green, W. W. L. Taylor, Forecasting the Impact of an 1859calibre Superstorm on Satellite Resources, Adv. Space Res., This volume. 2005. 
Philadelphia North American and United States Gazette, Issue dated August 29, 1859.

Providence Daily Post, Issue dated September 3, 1859.

Rochester Advertizer, Issues dated August 30, September 2, 1859.

Rocky Mountain Gold Reporter, Issue dated September 3, 1859.

Rocky Mountain News, Issue dated September 17, 1859.

The Daily Chronicle and Sentinel, Issue dated, September 8, 1859.

The East Floridian, Issue dated September 15, 1859.

The Hobart Town Mercury, Issues dated August 30, September 14, 1859.

The Illustrated London News, Issue dated September 24, 1859.

The Moreton Bay Courier, Issue dated September 7, 1859.

The Sydney Morning Herald, Issues dated August 30, September 1, 1859.

The Times London, Issue dated September 6, 1859.

San Francisco Herald, Issue dated September 5, 1859.

Scientific American, Issues dated October 15, November 12, November 26, 1859.

Washington Daily National Intelligencer, Issues dated August 31, September 2, September 3, September 5, September 6, 1859.

Washington Evening Star News, Issue dated September 2, 1859. 
Figure 1: A type A red aurora observed in Hokkaido, Japan on October 21, 1989 (near midnight due magnetic north). The deep rosy red aurora is very diffuse, with little or no structure and is observed to blanket nearly the entire sky similar to that observed by eyewitnesses of the great aurora of August 28-29 and September $2-3,1859$. The dark regions near the bottom of the image are clouds in this view on the beach over the ocean (courtesy of Dr. Takashi Maruyama, Japan). 
Science-PAO Committee Abstract

Eyewitness Reports of the Great Auroral Storm of 1859

James Green (green@mail630.gsfc.nasa.gov)

Scott Boardsen (boardsen@mail630.gsfc.nasa.gov)

Sten Odenwald (odenwald@mail630.gsfc.nasa.gov)

John Humble

Katherine A. Pazamickas (pazamickas@mail630.gsfc.nasa.gov)

Submitted to Advances in Space Research

Popular Summary

The great geomagnetic storm of 1859 is really composed of two closely spaced massive worldwide auroral events. The first event began on August $28^{\text {th }}$ and the second began on September $2^{\text {nd }}$. It is the storm on September $2^{\text {nd }}$ that results from the Carrington-Hodgson white light flare that occurred on the sun September $1^{\text {st }}$. In addition to published scientific measurements; newspapers, ship logs and other records of that era provide an untapped wealth of first hand observations giving time and location along with reports of the auroral forms and colors. At its height, the aurora was described as a blood or deep crimson red that was so bright that one "could read a newspaper by." Several important aspects of this great geomagnetic storm are simply phenomenal. Auroral forms of all types and colors were observed to latitudes of $25^{\circ}$ and lower. A significant portion of the world's 125,000 miles of telegraph lines were also adversely affected. Many of which were unusable for $\mathbf{8}$ hours or more and had a small but notable economic impact. This paper presents only a select few available first hand accounts of the Great Auroral Event of 1859 in an attempt to give the modern reader a sense of how this spectacular display was received by the public from many places around the globe and present some other important historical aspects of the storm. Historically these storms occur about once per 100 or 200 years. 